ISSN: 0213-3563

https://doi.org/10.14201/azafea2020224965

\title{
PARADOXES OF PAIN: A DIALOGUE BETWEEN PLATO AND CONTEMPORARY PHENOMENOLOGY
}

\author{
Paradojas del Dolor: un Diálogo entre Platón \\ y la Fenomenología Contemporánea
}

Bernat TORRES

UIC Barcelona

Recibido: 12 de marzo de 2019

Aceptado: 21 de agosto de 2019

\begin{abstract}
The paper presents a dialogue between contemporary phenomenology and Plato on the nature and complexity of pain. Taking as a departure point Drew Leder's “The experiential paradoxes of pain” the article delves into the essentially liminal character of pain. It focusses afterwards in two paradoxes that these experiences reveal. The first one is the one that describes the pain as a sensation and also as an interpretation. The second is the one that describes the pain as a destructive but also productive experience. We discuss throughout the article how the Platonic approach, although being much more holistic (in the sense of always combining the personal, ethical, political, and cosmological perspective), is not far from the phenomenological one. And we conclude that both methods try to limit and to describe an experience that escapes all limitations and determinations.
\end{abstract}

Key words: pain; pleasure; phenomenology; intentionality; paradox; apeiron; Plato.

\section{RESUMEN}

El artículo presenta un diálogo entre la fenomenología contemporánea y Platón sobre la naturaleza complejidad del dolor. Tomando como punto de partida el artículo de D. Leder "Las paradojas experienciales del dolor", el escrito profundiza en el carácter esencialmente liminal del dolor y luego 
se centra en dos paradojas que revela esta experiencia. La primera es la que describe el dolor como una sensación y también como una interpretación; la segunda es el que lo describe como una experiencia destructiva y también productiva. A lo largo del artículo veremos que el enfoque platónico, aunque sea mucho más holístico (en el sentido de combinar siempre la perspectiva personal, ética, política y también cosmológica), no está muy lejos de la fenomenológica. Que ambos enfoques intentan establecer límites y describir una experiencia que escapa a todas las limitaciones y determinaciones.

Palabras clave: dolor; placer; fenomenología; intencionalidad; paradoja; apeiron; Platón.

This paper aims to present a dialogue between contemporary phenomenology and the Greek tradition, represented by Plato, on the nature and complexity of the experience of pain. To do that, we depart from Drew Leder's exposition of different pain paradoxes in his article "The experiential paradoxes of pain” (Leder, 2016). The present paper aims at enriching Leder's description reviewing the common places between the phenomenological approach and the Platonic treatment of pain. We begin this exposition by comparing the general idea of pain understood as a liminal or paradoxical experience to deal, afterwards, with two of the paradoxes included in Leader's work. The first paradox is the one that describes the pain as a sensation and as an interpretation; that is, as a raw material from the senses and as an experience attached to an interpretation or a representation. The second is the one that describes the pain as a destructive or disruptive element for our experience and, at the same time, as a productive experience, meaning that from the experience of pain, some meaning or understanding can be built or learnt ${ }^{1}$.

Before starting the dialogue between the Greek tradition represented by Plato and contemporary phenomenology, at least two elements need to be pointed out. Firstly, in the Platonic sources and the Greek culture in general, pain always appears as being inseparable from pleasure and generally understood as its opposite. This inseparability is established in the Republic (583b and ff.) or the Philebus (31b and ff.), and presented, for instance, in the

1. The other paradoxes that Leder explains are: "certainty and uncertainty" "the present and the projective", "the never-changing and the ever-changing", "the mind and body", "self and other", "the here and everywhere", "the in-control and out-of-control" (Leder, 2016). 
dramatic scene of the Phaedo, where Socrates states, about pleasure and pain, that "anybody that pursues one of them and catches it, he's always pretty well bound to catch the other as well" (60b-c). The opposition between pain and pleasure seems to be connected with the idea of harmony, because both experiences are part, as we will see, of a process of constitution, disintegration or restitution of a certain harmony or natural state. The platonic source usually defends this opposition together with the idea of the existence of an intermediate state, which is neither pleasure nor pain (Philebus, 33b, and ff.) and, finally, with the idea that both experiences are forms of movement $(R e-$ public, $584 \mathrm{e}$ and ff.). From the phenomenological perspective, where notions like harmony (and especially in the sense of cosmic or metaphysical harmony) usually are absent, there is no explicit agreement about the opposition between pleasure and pain. Some approaches may treat them as opposites, like the one represented by Max Scheler (1913-16: 2000) or David Le Breton (2003), whereas in the most of the cases they are treated separately and understood as separate experiences (Buijtendijk, 1948; 1961; Scarry, 1985; Serrano de Haro, 2012a). The possibility of detaching these two experiences remains an important subject, but we cannot deal with it here.

Secondly, while for contemporary phenomenology and in general for modern thought and science, the central interest is located on pain (frequently detached from pleasure). For Plato and the Greek tradition, the primary interest is in the study of pleasure. These elements are quite surprising, given the fact that generally speaking, our society and life tend to be hedonistic. In contrast, ancient Greeks are thought to have lived a rather harsh and often not pleasurable life full of war, sufferings, and destruction. This fact could be, again, an intriguing subject for discussion, but we cannot go into it now.

The two aspects mentioned above, the higher centrality of pleasure over pain and the permanent connection between both experiences, determine a relevant point of our approach when we deal with the Platonic source. On many occasions, our statements about pain are not directly taken from the argument of the dialogues, but rather extrapolated from the discussion of pleasure. The reason for doing so is that, in most of the cases, Plato replaces clarifications on suffering by the more common clarification about pleasure.

As for the Platonic sources used in this paper, they are circumscribed to the discussion on pleasure and pain that we find in the Republic (583a-587d), the Timaeus (64a2-65b3) and the Philebus (31b-55c). The most careful study conducted in this field, still very unexplored, is the one by David Conan Wolfsdorf, who offers a vibrant analysis of the Timaeus's description of 
pain, also referring to the clarifications of the Republic and the Philebus (cf. Wolfsdorf, 2015). Also, the fascinating study by Mathew Evans (2007), from a more analytical perspective, finds the connections between the Philebus and the modern conception of pain as attached to representational content. Finally, the classic work of Gosling and Taylor (1982) also remains a valuable reference, although their approach focuses mainly on the experience of pleasure.

\section{The liminal, Paradoxical OR APEIRONIC CHARACTER OF THE EXPERIENCE OF PAIN}

The general idea that governs Leder's diagnosis of the contemporary phenomenological approach to pain and the idea that serves him to introduce the different paradoxes is the fact that this experience has a liminal or paradoxical character. This means that pain is an experience located in the in-between, in an indeterminate sphere between the body and the mind, between the immediate experience and the mediation of rationality and judgment. Pain, as Leder puts it, "inhabits an in-between state, a kind of nether region characterized by "ambiguity, paradox, a confusion of all the customary categories"”. (Leder, 2016, 458-459). This ambiguity can be seen by observing one of the most commonly used definitions of pain, the one offered by the IASP, where the pain is located between a sensation and an emotion and is, at the same time, associated, but not reduced to, a physical experience: "An unpleasant sensory and emotional experience associated with actual or potential tissue damage, or described in terms of such damage" (International Association for the Study of Pain, 2005). As Grüny $(2004,16)$ points out, this definition leaves open, as well as mixes, the clarification of notions like "unpleasant", "sensation" "emotio", or "tissue damage".

The liminal or paradoxical aspect of pain finds a clear and astonishing parallel in the work of Plato. As Socrates states in the Philebus:

pains and pleasures come to be set alongside one another simultaneously, and, as it just now came to light, of these contraries [pleasure and pain] sensa-

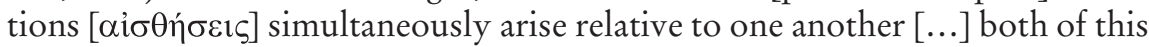

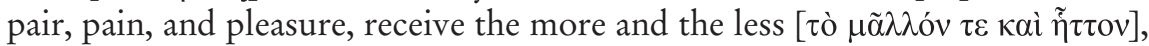
and as a pair, they belong to the unlimited [ä́cipov] things (Plato, Pbilebus, 41d1-8; trans. S. Benardete). 
That pain is an apeira, an unlimited or indeterminate reality, means that it belongs to the class of things that have the nature of the "more and the less" of all those realities that are always in flux, like the hotter and the colder or, the bigger and the smaller:

...in the case of the hotter and the colder, see whether you could ever conceive of some limit, or would the more and the less, which dwell as a pair of them, as long as the pair is dwelling within, disallow to the genera an end and completion to come to be, for when an ending occurs, the pair of them also has come to an end (Plato, Philebus, 24a-b) ${ }^{2}$.

It is important to stress here, as this represents an essential difference with the phenomenological approach, that the undetermined character of pain (and pleasure) is not only seen by Plato from the perspective of the human experience (or, in other words, from the first-person perspective that phenomenology tends to use) but also, and in an extreme sense, from a holistic or global perspective, a standpoint including a cosmological, ethical and even political view. This is made clear in the description of the cosmos as a whole constituted by four classes or types: the limit, the unlimited, the mixture between them, and the cause of the mixture. As Socrates states in a specific moment of the dialogue, "there are -it's what we have often said-an extensive unlimited in the whole and a satisfactory limit, and no inferior and shallow cause is presiding over them, ordering and arranging years, seasons, and months, and it is to be spoken of most justly as wisdom and mind" (Plato, Philebus, 30c1-6).

That means that pain and pleasure, as undetermined realities, share a similar nature with the unlimited in the whole (that is, of the unlimited as a constitutive part of the cosmic reality); the difference being that in the cosmic level the unlimitedness can be limited, measured or controlled thanks to the cosmic order or rationality (such as when, from the flux between hot and cold, the different seasons are created; cf. Philebus, 26b-c); while in the human dimension, the limit or the measure needs to be imposed by our human rationality and will, much weaker and much less effective than the cosmic nous. The Platonic attempt to introduce this limit and measure has a clear ethical and political intention in the fulfilment of a good life in the individual

2. See Aristotle and his references to the "diad" ("סvác") or to and "the more and the less"

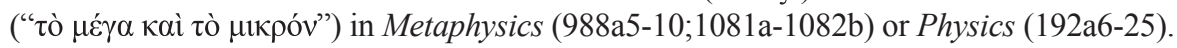


and the communitarian sense, an intention that is (or at least seems to be) absent in any phenomenological approach.

Despite all the differences in the way of approaching the question of pain as an unlimited experience or as a paradoxical experience, both the Platonic dialogue and the phenomenological approach, try to offer tools and strategies to describe the indescribable, to set a limit to the unlimited. As Serrano de Haro puts it, there is a need to go beyond the lived condition of pain toward "a categorical or, if you prefer, an ontological discussion [...] because pain occupies this purely frontier place, it is a kind of juncture located experience, that makes it perhaps the most bodily of the events of consciousness and at the same time the most conscious of the bodily phenomena" (Serrano de Haro, 2008, 87-88).

\section{Pain as A MERE SENSATION OR AS AN INTERPRETATION}

The first paradox which we deal with is the one described by Leder as "Sensation and Interpretation" a paradox concerned with the difficulty of determining whether the pain is a mere sensation without any intentional or representational character, or if it is something non-detachable from an interpretation or a representation. As Toombs (1992, 36-37) puts it, "pain thus partakes both in the immediacy of sensation and in the mediacy of complex referentiality and interpretation" For its relevance to understand the complexity of the experience of pain, this seems to be the most essential or primary of the paradoxes, at least from the phenomenological perspective; and this is so because the intentional character of pain furnishes it with an entity, with an ontological dimension, an entity that may get lost if we understand this experience to be a mere sensation or a non-intentional experience. Let's approach these two possibilities in some detail.

\subsection{Pain as a mere sensation, or the common position of Protarchus and Husserl}

On the one hand, pain can be seen as a mere or immediate sensation, which implies a comprehension of pain as raw reception of a stimulus, without any intentional content. To say that pain is a mere sensation means that we do not feel pain "of" or "for" something, but we just feel pain. As Elaine Sca- 
rry $(1985,161-162)$ states, pain, because of this lack of any referential content, is almost impossible to be rendered in language. Originally, the nonintentional character of pain has been defended by two of the most eminent phenomenologist, Carl Stumpf, and Edmund Husserl. He is in this aspect in confrontation with their master Franz Brentano. Stumpf and Husserl consider that physical pain is not a perception or something that happens in one's body, and neither exclusively a mere sensation, that is the reason why they use the term "effective sensation" ("Gefühlempfindung”) to describe it ${ }^{3}$.

In the Platonic context, this position is quite similar to the one defended by Protarchus and Philebus, who deny any possibility of introducing internal differences or determinations in the experience of pain as Socrates states referring to the value of pleasure and suffering for the two young hedonists, "although the majority of them are bad and there are good ones as well, as we assert, all the same, you address them all as good" (Plato, Philebus, 13b1-3). All pleasures and all pains, no matter the context, the representation content attached to them, are good and positive in the case of pleasure, both bad and negative in the case of pain ${ }^{4}$. As the dialogue shows, this means that independently of the intentional o representation character of the experience of pleasure and pain, these experiences are not affected in their essence qua pleasures and pains. Their reality is, in this sense, not intentional or representational. As we see later, the reality of pain and pleasure is essential, it's factuality, devoid of any characterization, that's why "we speak -says Protarchus- of the opinion as false at that time, but no one would ever address the pleasure itself as false (Plato, Philebus, 38a2-3)".

To fully understand this position, we need first to clarify what it means for an experience to be intentional. Intentionality indicates directedness or tension of the experience. It can be defined as "the power of minds to be about, to represent, or to stand for, things, properties and states of affairs" (Standford Dictionary). It represents a temporal connection between something which is subjective or has to do with my own (first person) perspective (the pole of "subjective" experience that we could call A), and an external element which is determined (the pole referenced to the object, which we call B). Intentionality implies too that the relationship between A and

3. For a detailed clarification of these positions, see Serrano de Haro (2010).

4. Precisely of the same opinion seems to be Aristippus of Cyrene when he states that "Pleasure is good even if it proceeds from the most unseemly conduct" (Diogenes Laertius, II, 86). 
$\mathrm{B}$ has a temporal nature, a temporality that allows the experience itself. For example, by seeing, I intentionally see a computer in front of me, determining its form and shape; by touching, I intentionally and kinesthetically get information from the keyboard that I use to write these words, an experience which points towards something external to the touching itself. Intentionality always implies an externalization of experiences, the fact that I am, that my experience is, directed towards the object of my experience. This is the meaning of technical notions like 'composition,' 'construction' or 'horizon' of the experience ${ }^{5}$.

To say that pain is not an intentional experience means, then, that this experience somehow abolishes or destroys the distinction between the poles of the intentional experience A and B. It is as if the pain would compress or squash the two poles, somehow fusing them and turning them into a mere sensation or, as Stumpt and Husserl defend, an "affective sensation" impeding in this way the experience to be intentional. Whereas the composition, as a result of the intentional experience, represents, as we have said before, a kind of being always moved towards something external, the destruction of this composition by pain implies rather a type of closure. This internal experience does not have, from itself, any reference to anything external. As Serrano de Haro states, "in physical suffering, perceptive and bodily sensibility, which is normally opened to the world, reverts inward, flows back, without any intentional exit, without a transitive vector to anything else, enclosed in a possibly unexpected revelation of itself" (Serrano de Haro, 2012b, 232).

5. "Husserl's thoughts on the phenomenological reduction, on temporality, on perception, on evidence, can all be integrated into a coherent pattern if we study them in their rapport with the concept of constitution. Furthermore, the concept of constitution is used by Husserl as an explanatory schema: in giving the constitution of an object, Husserl feels he is giving the philosophical explanation of such an object. Thus in our discussion of constitution, we are studying the explanatory power of phenomenology, and in relating other phenomenological concepts to the concept of constitution, we are studying what they contribute to the philosophical explanation that phenomenology attempts to furnish" (Sokolowski, R., (1970) The Formation of Husserl's Concept of Constitution). 


\subsection{Pain as an intentional experience or the common position of Socrates and Brentano}

On the other side of this first paradox, pain can be seen precisely as an intentional experience, as an experience which is not detachable from (and that can be even identified with) an interpretation or with some kind of representational content ${ }^{6}$. This intentional understanding of pain can be seen from different perspectives and in different contexts. Still, perhaps one of the clearest is the medical one, where the patients or the sufferers experience that "with each new interpretive perspective, the sensed pain itself changed in quality, intensity, meaning, and affective content" (Leder, 2016, 446). As Leder defends in his article, this paradox is somehow supported by modern neuroscience, since from this perspective, pain is an experience where sensitive, affective, and cognitive aspects are integrated (cf. Melzack \& Wall, 1991, 191). Initially, the intentional or content-bearing aspect of pain has been defended by the master of Husserl and Stump, Brentano, who considers pain to be similar to sadness or joy, experiences that always implies a representational or an objectifying act; in this sense, pain "is the intentional correlate of a sense-perception and of a concomitant feeling; and so the pain does lie in one's toe, not in one's consciousness, not in mind, not in the brain" (Serrano de Haro, 2010, 388). Pain, expressed from the Platonic viewpoint, can be somehow determined, limited, or classified. This is again the position defended, mutatis mutandis, by Socrates, who not only identifies internal differences inside of pain and pleasure but also associates -as we discuss in the following lines- the structure of these experiences with the structure of judgment (Philebus, 36c-38c).

Going back to a previous point, to consider pain an intentional experience means that this experience is directed or that it stands for something external

6. It's important to clarify here the different sense of 'interpretation' and 'representation,' a term that Leder is not using to describe the present paradox, but that has for us some relevance. The difference between both notions is that whereas interpretation focuses clearly in the active character of experience, representation remains in the inbetween, between interpretation and sensation. The reason being that representation has a passive role although being more active than a mere sensation; which means that in the case of representation, the cognitive element present in pain can be active or passive (like when we associate a particular representation to a painful sensation, for instance, in which case this cognitive element is not necessarily active). Be it as it may, in both cases, there is a determination of the experience of pain in both cases, that is, from the classical perspective, some kind of peras, limit or measure. 
to itself; in this sense, through the experience of pain, both poles A (the "subjective" pole) and $\mathrm{B}$ (the pole that is directed toward the object) remain separated and united through temporality. Pain is, then, not a simple reception of a stimulus, a raw or indeterminate experience, but instead implies some degree of determination. This fact, the understanding of pain as belonging to the class of experiences that produce, or allow, some kind of determination, is of great importance to establish the comparison with the Socratic position presented in the Philebus. In seeing pain as something attached to an interpretation, some kind of determination (peras) is introduced into the originally unlimited experience of pain (or pleasure):

Socrates: ... If we detect some pain, in its involvement with that for which [ $\pi \varepsilon \rho \grave{i}$ tò $\dot{\varepsilon} \varphi$ ' $\tilde{\varphi}]$ there is pain, in error, or its contrary, pleasure, in error, shall we apply "right" or "good" or any of the beautiful names to it? [...] it does look as if pleasure often comes to be for us, not with the right opinion but with falsehood.

Protarchus: Of course, it does. In a situation of that kind, Socrates, we speak of the opinion as false at that time, but no one would ever address the pleasure itself as false (Plato, Philebus, 37e5-38a3).

The fragment is illustrative of the two positions that we are describing. On the one side, Protarchus defends that pain is pain and pleasure is pleasure, they are understood as mere sensations (as a simple hedesthai or lypesthai) that do not admit any kind of intrinsic differentiation. Actually, he considers pain and pleasure as having an absolute factuality, a factuality that is unqualified as a mere sensation. On the other hand, Socrates, who does not deny this factuality, adds to it the possibility to classify and establish internal differences in the experience of pains and pleasures. The main result of the Socratic enquiry is to prove-against the position defended by Protarchus and Philebus- that pleasure cannot be simply identified with the good (and pain with the bad) and that there is a possible way to introduce measure into the naturally unlimited experience of pain and pleasure. To fully understand the Socratic position, and these internal distinctions, we need to clarify the relationship between the notions of harmony, perception, desire, and memory.

The Socratic attempt to classify and to introduce some degree of measure into pleasure and pain departs from the idea that this experiences, although being in themselves unlimited, are connected or derive from a state of harmony, a harmony that represents a general state of equilibrium, a good example of which would be health (cf. Plato, Philebus, 31d1-8; cf. Timaeus, 
64d1-8). Pain is then the experience that may accompany the dissolution of this harmony or may also be understood as emptiness felt in the body. In all occasions where a state of dissolution or emptiness appears and is perceived, a reaction or a countermovement towards harmony or fulfilment takes

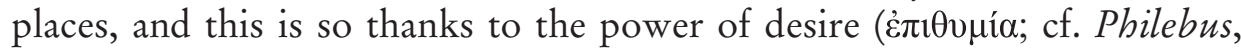
$34 \mathrm{c}-35 \mathrm{~d}$ ). Desire is a power of the soul that moves us toward "conditions opposite to the actual ones in the body, while it is the body that undergoes the pain and the pleasure of some affection" (cf. Philebus, 41c4-6). The power of desire, as the main feature that explains the presence of a structure inside the experience of pain and pleasure, is intimately attached to the power of memory $(\mu v \eta \dot{\mu \eta})$ or recollection. It is so because memory supplies the content or the direction toward which we should fulfil our emptiness: "By pointing out that it is the memory that directs it toward the objects of its desires, our argument -states Socrates- has established that every impulse, desire, and the rule over the animal is the domain of the soul" (Philebus, 35d1-4). So, when there is a destruction of a harmony (actual, imagined or expected) we automatically desire the opposite of the present state (felt in the body) and memory (or recollection) gives us the content (let us say the object) of this desire, a desire that is, in fact, felt as pain or emptiness. As Dorothea Frede $(1993,37)$ says, "the point of this careful analysis of the different factors is to establish that pains and pleasures are intentional (object-directed) states since all involve memory" Or, as Matthew Evans expresses it, "if pains are to play the role in practical reasoning that they manifestly do play, then they must have a structure that's similar to that of familiar content-bearing psychological states such as opinion, hope, anger, and the like" (2007, 91). It is precisely its connection with desire and memory that allows us to understand the intentional or representational character of the experience of pain.

The intentional or representational character of pain is introduced in the Philebus through the presence, in any pleasurable or painful experience, of a judgement or opinion ( $\delta$ ó $\xi \alpha$; cf. Philebus, $36 \mathrm{e} 7$, and ff.) that can modify and transform the experience itself. This can be seen in the quote mentioned above, where pleasure and pain imply a reference to reality (a $\dot{\varepsilon} \varphi$ ' $\tilde{\omega}:$ or a $\pi$ oĩos $\tau \iota \varsigma$, cf. 37c2-4) made through a judgement that may be mistaken ( $\dot{\alpha} \mu \alpha \tau \tau \dot{\alpha} v \omega)$, affecting in this way the factual experience of pain. This error or mistake from the pains and pleasures is the specific place where the paradox that we are dealing with can be placed. For Protarchus, there is no possible mistake or error in the experience of pain or pleasure (because these experiences don't accept internal differences), but for Socrates, this error can take three 
different forms (cf. Philebus, 36c-41a; 41a-42c; 42c-46b). In the Socratic account, the presence of representations (or misrepresentations) affecting the actual experience of pain and pleasure has to do, as we have seen, with the relationship between these experiences, perception, memory and desire and implies, in fact, not only the complex nature of pain itself but also our whole comprehension of the present, the past and the future of our existence. This is so because we always tend (through the power of desire) to move toward a possible or imaginary fulfilment identified with a representation of what we think is right, a representation, or expectation that may be qualified as true or false. An interesting difference with the phenomenological approach is to be found here: whereas the phenomenological approach may defend the existence of an interpretation or a representation (or misrepresentation) as modifying the mere sensation of pain, this modification is not understood in terms of right and wrong or, much less in term of what is good or bad. This has to do with the intention of neutrality of the modern phenomenological approach.

Of course, as in the contemporary discussion, the problem as well how exactly a judgment (or any form of representation or interpretation attached to the factual experience), can affect or modify the actual sensation of pain. Leder $(2016,446)$ points toward a very concrete explanation of this fact, indicating how the interpretation of a particular pain transforms its felt quality or intensity. The modification of the degree and intensity of the experience of pain as a consequence of an interpretation or expectation that is not part of the content of the sensation itself is also underlined by Eric J. Cassel (1982, 641), who explains how specific interpretations of pain imply a higher degree of suffering: "people in pain frequently report suffering from the pain when they feel out of control, when the pain is overwhelming, when the source of the pain is unknown, when the meaning of the pain is dire, or when the pain is chronic.” In a similar sense, Christopher Hill $(2005,95)$ develops the idea of the "substantial amount of misrepresentation" associated with the experience of pain.

Finally, it is worth noting that the presence of the power of desire or eros in the Socratic argument, the power that allows us to understand that the essentially irrational experience of pain can find a direction, a solution that implies memory and judgement, finds a parallel in the phenomenological description through the notion of Erfüllung, the so-called fulfilment structure, the fact of filling significant intentions of specific actions through an intuitive content. What I take to be a certain way or manner tends to 
manifest itself in what Husserl calls an experience of fulfilment (Erfüllung); an experience where we are aware of the grounds for taking something in a certain way, and we are aware that we are rational in virtue of being aware of these grounds. That happens, for instance, when the hidden or backside of an object that we are observing is how I took it actually to be (Husserl, 1950, $\$ \$ 24-27 ; 1976$, $\$ \$ 136-38)$.

\section{The Destructive AND PRODUCTIVE CHARACTER OF PAIN}

Finally, let us discuss the second paradox, the one that Leder calls "the productive and destructive" character of pain. This paradox has to do with the fact that pain involves a destructive character and a productive or positive one. The destructive character of pain has to do with its character as an experience "overturning all that makes life enjoyable, convivial, purposeful, and meaningful” (Leder, 2016, 457; cf. Scarry, 1985, 29). The phenomenologist Christian Grüny, in his book Zerstörte Erfabrung. Eine Phänomenologie des Schmerzes (Destruction of experience. A phenomenology of pain) defends that the irruption of pain is always a disturbance of the experience, a disruption in the normal activities in everyday life that can be defined as a "blocked movement of flight" (eine blockierte Fluchtbewegung) (Grüny, 2004, 118). By that, he means that pain, which is essentially a process, a movement, produces harming negativity that cannot be ignored or deactivated, it can just be suffered as it is (Grüny, 2004, 166). The conception of pain as destruction, or destitution (or as a crisis of the experience) is intimately connected with the idea of composition or intentionality that has been previously clarified. If there is a destruction of the experience or the perceived world, that means that, somehow, the intentional or representation character of pain precedes conceptually and factually its dimension as destruction. Pain, when it is experienced in our body, impedes and destroys the normality of our existence, this is the meaning of the first extreme of the paradox we are dealing with.

On the other hand, pain may contain a positive or productive aspect because it may generate new questions and meanings; it may inform us about the existence of a problem, indicating as well how to solve it; it may awaken a comprehension of our existence, our actions and, in general, of the sense of life. Effectively, pain can generate new questions, and meanings about how I should treat and prevent pain in the future, "Hopefully -as Leder states- the messages received 
are both beneficial and practicable. With proper rest, self-care, exercise, the back problem may resolve- lesson learned (Leder, 2016, 457).

If we now move to the Platonic source, we see that description of pain contains both a destructive and productive character. As for its destructive character, it can be found in the very definition of pain that can be found both in the Philebus and the Timaeus. In the first dialogue, pain is associated with destruction and, specifically, with violent and sudden destruction of a state of harmony; when this harmony is dissolved "in us animals [...] the simultaneous genesis of pains" takes place, and "when that nature is being fitted back together again and is returning to its own nature, we have to speak of the coming into being of pleasure" (Plato, Philebus, 31d1-87). A very similar idea is expressed in the Timaeus "An impression produced in us contrary to nature and violent, if sudden, is painful; and, again, the sudden return to nature is pleasant; but a gentle and gradual return is imperceptible and vice versa (Plato, Timaeus, 64d1-4; trans. B. Jewett).

In both cases, pain and pleasure appear as forms of movements that are opposite to each other concerning a state of harmony, a natural state, or an adequate condition (cf. Philebus, 34a3-5; Timaeus, 43c4-7). This natural or

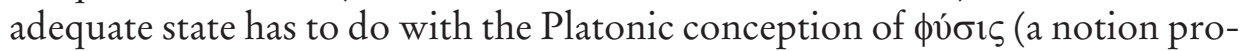
bably influenced by the Hippocratic view) that determines the constitution of the human body as a harmonious relationship between dynamic elements that produce a general unity and stability. This harmony is identified in the Philebus with a kind of measured mixture between ö $\pi \varepsilon 1 \rho \circ v$ and $\pi \varepsilon \dot{\varepsilon} \rho \varsigma$ as it is found, for example, in health (cf. 28e8-9), musical rhythms (cf. 26a24), meteorological stability (cf. 26a6-8) and also in beauty and strength (cf. 26b4-5). There is no pain without the destruction of this harmonic or adequate state and, at the same time, this destruction, to be perceived as pain, needs to be violent, because gentle movements always remain unperceived

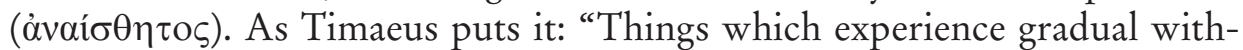
drawings and emptyings of their nature, and great and sudden replenishments, fail to perceive the emptying, but are sensible of the replenishment; and so, they occasion no pain" (Plato, Timaeus. 65a1-7).

The Platonic source also furnishes us with at least two aspects that can be seen as productive or constructive in the comprehension of pain. The full development of each of these aspects would exceed the extension of this paper by far; that's why we only describe them shortly. The first sense into which

7. Cf. Merker (2004, 15-16). 
pain can be seen as a productive experience has to do with the representational or content-bearing aspect of it as explained before; every painful experience implies the presence of certain kind of judgement that may be correct or incorrect, and that represents or reflects (being in this sense informative about) some aspect of reality. The second aspect is the educational or political relevance of pains and pleasures, the fact that for Plato, these experiences need to be shaped in conformity with a particular idea of what is right and what is wrong for the community. That is why everybody, and especially the child, needs to be "rightly trained in respect of pleasures and pains, to hate what ought to be hated, right from the beginning up to the very end, and to love what ought to be loved" (Plato, Laws, 654b1-c2; trans. R. G. Bury). This kind of education is exemplified through athletics or gymnastics (Plato, Timaeus, 89a; Republic, 403c-404e) and also through dance (Plato, Laws, 653a-654d) (cf. Moutsopoulos, 1989).

The educational dimension of pain could be complemented with its relevance as a form of punishment in its service to ensure and reach the city's political order and its souls. Indeed, physical pain is said to be needed to repair an injustice (cf. Plato, Gorgias, 525b-c). However, the real punishment is the one that is inflicted in the soul of the criminal, mainly through the experience of shame (cf. Plato, Laws, 855a-c; 862d-e; 949c-d). As Ann Merker points out, the function of the body (through the experience of physical pain) is a semantic one; this is so because once it has been punished, our body indicates, through the scars or whatever consequences resulting from the punishment, the state of the soul. In this sense, the body is understood as a sign (as a 'sema'), because through it, "the soul signifies whatever it wants to signify" (cf. Plato, Cratilus, 400b-c; trans. C.D.C. Reeve) (cf. Merker, 2004, 42-48).

\section{ConClusions: Plato's holism vs. PHENOMENOlOgical CONCRETENESS} IN THE STUDY OF PAIN

To summarise this comparative exercise, we see that the Platonic approach to the experience of pain is much more holistic than the phenomenological one. Whereas the latter sees the destructive character of pain mainly as a world-destructive experience seen from the first-person perspective (when I feel pain my attention is distracted; my relations with the others and the world are disrupted, and the like), in the Platonic description this destruction is also attached, to a more general notion of harmony and even to the notion 
of the order of the city and the soul. This general notion of harmony, of a natural state, is clearly absent in the phenomenological approach, possibly due to the fact from the modern view, nature is seen as somehow detached from human nature. From our point of view, this fact has essential consequences in the way we understand (and experience), both pain and pleasure.

The Platonic way of dealing with pleasure and pain, although including a phenomenology of the first-person experience, never stops there, but it continuously aims to encourage a change in the attitude of the listener, revealing what is good and bad at the personal, ontological and also political and educational level. Whereas the phenomenological approach always addresses the clarification of the first-person experience to complete -and maybe even laying the foundation for- the naturalistic and the constructivist or historicist perspective ${ }^{8}$. Nevertheless, as Geniusas points out, many of the contemporary philosophical attempts to describe pain tend to see it from a physiological perspective, from what he calls a physicalist ontology, because "they aim to show that pain, just as other bodily sensations, has an object, and that this object has a reserved place within a physicalistic ontology" (Geniusas, 2013, 2 ). In both cases, the objective is to find the unity of a complex and paradoxical experience presented in manifold ways and forms in our everyday lives.

\section{REFERENCIAS}

Buytendijk. F. J. J. (1948). Über den Schmerz. Medizin. Verlag Huber.

Buytendij, F. J. J. (1961). Pain. Trans. E. O’Shiel. Wesport, CT: Greenwood Press. Cassel, E. J. (1982). The Nature of Suffering and the Goals of Medicine. The New England Journal of Medicine, 306/11, 639-645.

Evans, M. (2007). Plato and the Meaning of Pain. Apeiron, 40/1, 71-93.

Frede, D. (1993). Plato. Philebus, Indianapolis.

GeniUsAs, S. (2013). On naturalism in pain research: a phenomenological critique, Metodo, International Studies in Phenomenology and Philosophy, 1/1, 1 .

Gosling, J. C.B \& Taylor, C. C. W. (1982). The Greeks on Pleasure. Oxford University Press

8. As Saulius Geniusas $(2013,1)$ asserts: "In the Logos article, Husserl aimed to position phenomenology between two methodological extremes, which might have seemed to be the only viable positions. Supposedly, when it came to methodological issues, one could either be a naturalistic, or one could be a historicist, and it might have seemed that there is no other attitude one could take on". 
Grüny, Ch. (2004). Zerstörte Erfahrung. Eine Phänomenologie des Schmerzes. Wuzburg: Königshausen \& Neuman.

Hill, Ch. (2005). Pain: New Essays on Its Nature and the Methodology of Its Study Husserl, E. (1950). Cartesianische Meditationen und Pariser Vorträge. Edited by S. Strasser. The Hague: Martinus Nijhoff.

Husserl, E. (1976). Ideen zu einer reinen Phänomenologie und phänomenologische Philosophie. Erstes Buch: Allgemeine Einfübrung in die reine Phänomenologie. Edited by K. Schuhmann. The Hague: Martinus Nijhoff.

Le Breton, D. (2003). Schmerz. Eine Kulturgeschichte, Zürich u. Berlin: Diaphanes Verlag.

LEDer, D. (2016). The Experiential Paradoxes of Pain. Journal of Medicine and Philosophy, 41, 444-460.

Melzack, R. \& P. D. Wall (1991). The Challenge of Pain. London: Penguin.

Merker, A. (2004). Corps et châtiment chez Platon. Études platoniciennes, 1.

Moutsopoulos. E. (1989). La Musique dans l'oeuvre de Platon. Paris: P.U.F.

Serrano de Haro, A. (2010). Is Pain an Intentional Experience? Phenomenology, 3, 386-395.

ScArry, E. (1985). The Body in Pain: The Making and Unmaking of the World. New York: Oxford University Press.

SCHeler, M. (1913-1916). Der Formalismus in der Ethik und die materiale Wertethik, Neuer Versuch der Grundelung eines Ethischen Personalismus, Felix Meiner Verlag, 2014.

SCheler, M. (2000). El formalismo en la ética y la ética material de los valores. Madrid: Caparrós.

Serrano de Haro, A. (2008). En los límites de la fenomenología: el análisis del dolor físico. VI Jornadas Nacionales de Fenomenología y Hermenéutica "Sentido, libertad y destino". 87-99.

Serrano de Haro, A. (2012a). Elementos para una ordenación fenomenológica de las experiencias aflictivas. Anuario Filosófico 45/1, 121-144.

Serrano de Haro, A. (2012b). New and Old Approaches to the phenomenology of pain. Studia Phenomenologica, 12, 227-237.

Wolfsdorf, D. (2015). Plato on pain. Antiquorom Philosophia. An International Journal, 9, 11-26. 
